\title{
Revenant modernisms and the recurrence of literary history
}

\author{
"Enter the ghost, exit the ghost, re-enter the ghost (Hamlet)" \\ (Jacques Derrida, Specters of Marx)
}

\author{
MATTHEW SCHULTZ* \\ Vassar College
}

Received: 02/05/2016. Accepted: 12/12/2016.

\begin{abstract}
This essay suggests that literary production post-postmodernism has not progressed to something new, but rather has returned to quintessentially modernist anxieties and modes of expression - especially renewed faith in grand narratives. The argument draws upon and coalesces two theoretical texts to help identify what I term "revenant modernism' as a "symbolic space" (Flatley, 2008: 32) where a sort of "secular re-enchantment" (Landy \& Saler, 2009: 2) remains possible: Jonathan Flatley's Affective mapping: Melancholia and the politics of modernism (2008) and The re-enchantment of the world: Secular magic in a rational age (2009) by Joshua Landy and Michael Saler. I then examine two recent novels-Will Self's Umbrella (2012) and Eimear McBride's A girl is a half-formed thing (2014) - as evidence of this return. Along the way, I tie both of these novels back to their stated modernist influence (James Joyce's Ulysses [1993]) in order to show how Self and McBride's fiction borrows from Joyce's particular brand of postcolonial modernism.
\end{abstract}

KEYWORDS: James Joyce, feminism, grand-narratives, String Theory.

\section{HAUNTOLOGY AND POSTCOLONIAL MODERNISM}

In a recent Modernism/modernity article titled "Modernism Post-postmodernism", Luke Smythe observes, "[i]n the wake of postmodernism has come a widespread interest in the art world in revisiting the fate of modernism in the visual arts" (2015: 365). The same can be said of literary modernism. My aim, however, is not to understand the "fate" of the twentiethcentury's most robust artistic movement as some past concept that is dead and gone, but

\footnotetext{
*Address for correspondence: Matthew Schultz. Vassar College, 124 Raymond Avenue, Box \#505,
} Poughkeepsie, NY 12604, United States; e-mail: maschultz@vassar.edu. 
rather to suggest that a century later, at the beginning of the twenty-first century, we are experiencing something of a revenant modernism wherein contemporary fiction puts on display the anxieties and experimental modes of expression more commonly found in the literature of the early-twentieth century.

How might the revenant, or specter, help us to better understand such a return? In Specters of Marx (2006), Jacques Derrida introduces the concept of hauntology, which we can use to chart the ways that modernist aesthetics continue to haunt postcolonial fiction and vice versa. For Derrida insists that conjuration is an act of alliance:

It is a matter of neutralizing a hegemony or overturning some power. (During the Middle Ages, conjuration also designated the sworn faith by means of which the bourgeois joined to together [sic], sometimes against a prince, in order to establish free towns.) In the occult society of those who have sworn together [des conjurés], certain subjects, either individual or collective, represent forces and ally themselves together in the name of common interests to combat a dreaded political adversary, that is, also to conjure it away. (2006: 58-59)

Said another way, subaltern figures - those existing outside of the hegemonic power structure - can conjure together to conjure up silenced voices in order to conjure away an established hegemony. Inviting ghosts to speak, however, is no simple task; Derrida insists, "[w] hat seems almost impossible is to speak always of the specter, to speak to the specter, to speak with it, therefore especially to make or to let a spirit speak" (2006: 11; his emphasis). Despite this seemingly impossible task, works such as Will Self's Umbrella (2012) and Eimear McBride's A girl is a half-formed thing (2014) attempt to give voice to the specters of literary history.

The postcolonial impulse in these novels is to recover the cultural identity of those at the margins of society - specifically, a doubly repressed figure: women with assumed mental illnesses. As Gayatri Spivak insists, "the subaltern has no history and cannot speak, the subaltern as female is even more deeply in shadow" (1998: 287). And as Eugene O'Brien contends, "[t]he experience of colonization was very different for women: they were the repressed by the repressed in many instances" (2008: 47). Self and McBride put on full display the issue of gender inequality. To wit, the subaltern position in Will Self's Umbrella is interstitial: the encephalitic Audrey Death lingers, comatose, between life and death. Meanwhile, the subaltern of Eimear McBride's A girl is a half-formed thing is the nameless young woman of the book's title who exists in the space between prudence and madness. The interstice is key to understanding how developments in modernist aesthetics emerge from their immediate cultural contexts and also how literature looks beyond its present moment and medium, revising models inherited from the past and anticipating future forms of literary expression. 
Of course, representations of otherness are never simple. Audrey Death is an Englishwoman, a Londoner to be exact. She is at the center of the British Empire in 1918. Yet, as a woman committed to a mental asylum, she is no more an agent of that empire than the nameless narrator of $A$ girl is a half-formed thing - an Irish woman who has suffered both mental abuse by her mother's religion and sexual abuse by the hand of her uncle. Both women, then, are doubly repressed because of their gender and damaged psyches - Death at the Imperial Center, and the nameless Girl beyond the pale in the West of Ireland.

To shine light upon the shadows that obscure these outcasts, to invite these repressed women back into the fray of society, and to suggest that their unique consciousnesses hold some deeper meaning is the work of Postcolonial Theory and subaltern studies. Robert Young assures us, "[t]he sympathies and interests of postcolonialism are thus focused on those at the margins of society, those whose cultural identity has been dislocated or left uncertain" (2003: 114). But where and how do modernist aesthetics intersect with the postcolonial agenda in contemporary literature? To answer this question, I draw upon and coalesce two theoretical texts to help identify revenant modernism as a "symbolic space" where a sort of 'secular re-enchantment' remains possible: Jonathan Flatley's Affective mapping: Melancholia and the politics of modernism (2008), and The re-enchantment of the world: Secular magic in a rational age (2009), by Joshua Landy and Michael Saler.

In his book, Affective mapping: Melancholia and the politics of modernism (2008), Jonathan Flatley proposes a new understanding of modernism that does not rely upon the traditional boundaries of temporality, geography, or generic convention. Rather, he suggests that the "insecure position between the promises of modernity and the realities of modernization is the place of modernism itself [...]. This means that the situation of modernism is one in which modernization is felt to be incomplete, still in progress, and thus potentially redirected" (2008: 32). In other words, Flatley would have us believe that modernism is not simply about formal experimentation, obfuscation, and subjective consciousness, but that there is a necessarily attendant social component of modernist aesthetics. Flatley goes on to maintain, "Modernism, in this sense, would refer not to any one thing in particular, but to the wide range of practices that attempt in one way or another to respond to the gap between the social realities of modernization and the promises of the project of modernity" (2008: 32). In this way, modernism becomes the "symbolic space" (to borrow one of Flatley's terms [2008: 32]) between "the promises of modernity" and "the realities of modernization". In short, the place of modernism is interstitial. And this space between, as it were, is a spectral site: one where the ghosts of the early-twentieth century continue to haunt contemporary texts. For, "if you let it, the ghost can lead you toward what has been missing, which is sometimes everything" (Gordon, 2008: 58).

I identify the promises of modernity as a latent sense of belonging amidst the grim realities of modernization: the key disruptive events of the 1910s and 1920s destroyed social and political paradigms that had championed order, efficiency, completeness, and objectivity. 
Advancements in communication and transportation technologies fractured cultures and often led to anxieties concerning dehumanization and alienation, developments in military weaponry and guerilla strategy showcased during The Great War of 1914-1918 and subsequent Irish wars (1921-1923) dehumanized soldiers, and the loss of faith that accompanied the weakening and eventual fall of the British Empire resulted in nostalgia for lost ideologies (such as the myth of progress). These upheavals of community exceeded the existing capacity of literary imagination to express them sufficiently.

Clearly, the violent crucible of world war and decolonization is a primary influence upon the work of twentieth-century writers; however, I also recognize that we should not reduce modernism to wholesale cause and effect. To be sure, military conflict haunts both Umbrella and $A$ girl is a half-formed thing. Yet these ghosts, I want to suggest, can help us fill the gap between the promises of modernity (order, efficiency, completeness, and objectivity) and the realities of modernization (dehumanization and alienation). If Joshua Landy and Michael Saler are correct that literary modernism can be understood as a process of secular re-enchantment, as I think they are, and if we can locate this process of reenchantment in Jonathan Flatley's "symbolic space", as I think we can, then reading contemporary fiction as an extension of such an aesthetic project can help twenty-firstcentury readers map a clearer connection to our literary past and, therefore, provide a better understanding of modernism's enduring influence in the present. Landy and Saler believe that

[i]f the world is to be re-enchanted, it must accordingly be reimbued not only with mystery and wonder but also with order, perhaps even with purpose; there must be a hierarchy of significance attaching to objects and events encountered, individual lives, and moments within those lives must be susceptible again to redemption; there must be a new, intelligible locus for the infinite; there must be a way of carving out, within the fully profane world, a set of paces which somehow possess the allure of the sacred; there must be everyday miracles, exceptional events which go against (and perhaps even alter) the accepted order of things; and there must be secular epiphanies, moments of being in which, for a brief instant, the center appears to hold, and the promise is held out of a quasi-mystical union with something larger than oneself. (2009: 2)

Now, if the world is to be re-enchanted, then it must leave open the possibility for compelling grand narratives. Indeed, as Landy and Saler mean this as a guide for contemporary crypto-modernist artists seeking once again to order the historical fragments of the twentieth century, they intentionally echo the terms and images found in works by James Joyce (epiphanies), Virginia Woolf (redemption), T. S. Eliot (allure of the sacred), Gertrude Stein (objects imbued with purpose), Marcel Proust (a center that appears to hold), Franz Kafka (everyday miracles), and others. If postmodernism is marked by a disenchantment or disillusionment (which we will get to shortly), then this revenant modernism of which I am 
speaking is marked by a correlating re-enchantment especially in novels like Umbrella and $A$ girl is a half-formed thing. My hope is that identifying this strategy employed by contemporary writers will lead to a more nuanced understanding of postcolonial modernism and its continuing significance within the larger framework of a revenant literary modernism in the early twenty-first century.

\section{MODERNISM POST-POSTMODERNISM}

The question at hand, then, is why contemporary authors continue to draw influence from a century-old mode of expression, one primarily concerned with the 'Nowness' of 'Then'. As Vincent Sherry points out, "Modernism: the suffix adds the special intensity of a faith or belief to the root sense of the Latin 'modo'- 'today' 'now,' or, most accurately, 'just now.' 'Modernism,' accordingly, suggests an acute awareness of a temporal present, all in all, an empowering awareness of living in a Now distinctly different from a Then" (2015: 32). To answer this question, we might return, briefly, to Jonathan Flatley's sense that, "the situation of modernism is one in which modernization is felt to be incomplete, still in progress, and thus potentially redirected. It also means that the promises of modernity are still felt to be relevant, vital, and achievable" (2008: 32). While the military campaigns of the first half of the twentieth century have ended, the social revolution (feminism in particular) is still very much a struggle. Contemporary authors working to represent this struggle as a means for better understanding the effects of such persistent inequality have put on full display the fragmented consciousnesses of female narrators. Not only do Umbrella and A girl is a halfformed thing examine a central representational problem for modernist authors - the unstable consciousness - , they also engage in formal experimentation reminiscent of High Modernism. ${ }^{1}$

This move into the subjective perceptions of the narrator echoes modernism's increased understanding of human psychology and a rising interest in the unconscious. Like their predecessors, Self and McBride provide narrators who enter into states of confused selfdeception. Thus, their stories become examples of human isolation and incomprehension. For instance, we could look to Joseph Conrad's “The secret sharer" (2002), which includes the narrator's admission of isolation and confusion: "At that moment I was alone on her decks. There was not a sound in her-and around us nothing moved, nothing lived, not a canoe on the water, not a bird in the air, not a cloud in the sky [...]. But what I felt most was my being a stranger to the ship; and if all the truth must be told, I was somewhat of a stranger to myself" (2002: 180-181). We hear a similar strangeness of the unfamiliar self from the narrator in $A$ girl is a half-formed thing who has recently been raped by her uncle: "I feel big and vast and my head's buzzing all round my voice. And every stuff. Hmm everything 
strange" (2014: 93). This is no isolated instance in McBride's text that uses the word "strange" seventeen times to describe not only the character's confused sense of herself, but also a disorientation of place and time: "The house will still be quiet. If I go there. Drip the floor. I felt this morning strange" (2014: 61). ${ }^{2}$ This bit of internal dialogue begins coherently enough. Should the narrator return home, the house will remain quiet because she has no one with whom to speak. Yet the next sentence complicates the silence as something drips upon the floor. We are given no indication of the substance that drips, the volume of it splashing upon the floor, nor its reverberation in the Girl's mind. What follows is simply the narrator's declaration of sustained confusion.

The Girl's litany of unanswered questions calls to mind the ambiguous and frustrating works of Franz Kafka. Particularly, I think of the most famously disorientating scene in modernist literature, the opening lines of The Metamorphosis:

As Gregor Samsa awoke one morning from uneasy dreams he found himself transformed in his bed into a gigantic insect. He was lying on his hard, as it were armor-plated, back and when he lifted his head a little he could see his domelike brown belly divided into stiff arched segments on top of which the bed quilt could hardly keep in position and was about to slide off completely. His numerous legs, which were pitifully thin compared to the rest of his bulk, waved helplessly before his eyes. What has happened to me? he thought. It was no dream. (1993: 75).

Here the house is quiet except for the scrape of the vermin's back upon the floor while his legs wave helplessly. The narrator has unexpectedly and inexplicably transformed into a cockroach while he was asleep. Upon waking, he cannot recognize himself even as he identifies "his domelike brown belly" and "his numerous legs". Gregor's confusion haunts both McBride and Self as it echoes the anxiety displayed by the Girl who can no longer feel at home in her own body because it has been claimed/raped by another, and later in Umbrella by Audrey Death. For example, when Dr. Zachary Busner successfully wakes Death from her 49-year coma, she cannot recognize her aged self:

Taking [the newspaper] from him Audrey, unfolds its rattling skirting. She looks to her hands and stumbles, Who-Whose are these... old hands, is - is this my morbid affliction? Then a photograph of the lunar Roving Vehicle on the front page catches her eye.-What an otherworldly motor car, she says, the chauffeur appears to be wearing a diving apparatus — and the brolly they've mounted behind the dickey is... is upside down! (Self, 2012: 212-213)

Death's own hands are as unrecognizable to her as this otherworldly Lunar Rover! Like Samsa, who is full of questions ("What has happened to me?"), Death similarly gropes for 
understanding ("is this my morbid affliction?"). Of course, in true modernist fashion, no answers are forthcoming.

Following the Second World War, cultural production took a postmodern turn characterized by an increased ontological uncertainty (McHale, 1987: 3) that leads to a lost sense of history (Jameson, 1991: ix) and "incredulity towards meta-narratives" (Lyotard, 1984: xxiv). L'humour noir, ironic detachment, and an oscillation between authorial presence and absence served to capture the mental crisis of an existence seemingly without meaning. In Postmodernist fiction (1987), Brian McHale distinguishes between an epistemological literary modernism and an ontological literary postmodernism. Modernism, McHale claims, is concerned mainly with interpreting the world and one's role in it while postmodern texts look inward by asking, "What world is this?", "Which of my selves will interact with this 'plurality of constructions'?" (1987: 3). Yet Umbrella and A girl is a half-formed thing are primarily examples of modernist epistemology - concerned, ultimately, with interpreting and representing a world that cannot be fully understood through the perspective from which these fractured narrators experience it. As such, Dr. Busner (Umbrella) spends the novel seeking to reconcile his success in waking encephalitic patients with the experimental drug, L-dopa, with his patients' feelings of violent displacement. They are simultaneously uncomfortable in this advanced time and their own skin. Dr. Busner is capricious, unsure he can arrive at some justifiable achievement, but strives nonetheless to find it. The doctor's hope similarly infects A Girl when the narrator's brother-known only as "You"-is confident that his brain cancer will go into remission even as his hospice doctor informs him that his condition is worsening: "When am I going to get well", he asks (McBride, 2014: 193).

Such optimistic expectations in the face of catastrophe is a hallmark of literary modernism, and can be seen in any number of earlier modernist texts. The ghost that looms largest here - both Will Self and Eimear McBride list it as a primary influence — is that "book to which we are all indebted, and from which none of us can escape" (Eliot, 1975: 175), James Joyce's Ulysses. In the "Aeolus" episode, Stephen Dedalus likens "two old Dublin women on the top of Nelson's Pillar" (Joyce, 1993: 121), eating plums, and looking out at all the places they will never visit, to Moses standing atop Mount Pisgah sighting the Promised Land in the faraway distance, but knowing that he will never reach it (Deuteronomy 34.4). Stephen titles their perspective "A Pisgah sight of Palestine" (Joyce, 1993: 122). John Bishop contends that Stephen's title is meant to suggest that, “[ $t]$ he process of reading is like Moses's trip through the desert to the top of Mount Pisgah. You'll get to the top of the mountain and see the Promised land of wrapped up meaning, but you're never going to get there [...] [modernism] strives to find - but doesn't believe it can find - a meaning that is complete and final and wrapped up" (2008). I think it is in this act of striving for new grand-narratives that modernism and postmodernism differ most drastically, and also where twenty-first-century fiction in Ireland returns to the philosophical and aesthetic modes of modernism. Striving to 
construct grand-narratives is one contemporary practice in "the wide range of practices that attempt in one way or another to respond to the gap between the social realities of modernization and the promises of the project of modernity" (Flatley, 2008: 32).

Modernist aesthetics and trauma studies both tend to emphasize the fragment; however, "the promise is held out of a quasi-mystical union with something larger than oneself" (Landy \& Saler, 2009: 2). While Ezra Pound concludes his Cantos by admitting that "I cannot make it flow through" (1966: 817), he did spend a lifetime wandering in the desert of thought in hopes of doing so. Similarly, James Joyce insisted that "there must be everyday miracles, exceptional events which go against (and perhaps even alter) the accepted order of things" (Landy \& Saler, 2009: 2) when he declared, "[A writer is] a priest of eternal imagination, transmuting the daily bread of experience into the radiant body of everliving life" (Joyce, 2007: 195). Both authors used pastiche, parody, and discordant language in the early-twentieth century to search for meaningful conceptual and formal structures underlying our fragmented reality.

This results in protean texts that exhibit the characteristics of a specter as defined by Jacques Derrida in Specters of Marx: "The specter is [...] what one imagines, what one thinks one sees and which one projects - on an imaginary screen where there is nothing to see" (2006: 125). Will Self produced a text whose spectral design invites "performative interpretation", a critical mode that is similarly employed by Derrida for the examination of ghosts: "that is, an interpretation that transforms the very thing it interprets" (Derrida, 2006: 63): Hauntology allows us to problematize the ghost, to see it always as "two thinks at a time" (to borrow a phrase from Joyce's Finnegans Wake [2012: 583]). The specter at the center of both Umbrella and A girl is a half-formed thing is simultaneously the female subaltern and her fragmented stream-of-consciousness. Additionally, the narratives, like the characters they chart, are themselves fragmented. They oscillate between free indirect discourse and stream of (un)consciousness as they shift among different voices and temporalities.

This technique is clearest in Umbrella, which disorients the reader by moving nonsequentially through time between 1918, 1971, and 2010 while narrating events in the already much quoted "continuous present" (Self, 2012: 235). Telegraph reviewer Lucy Daniels reminds us that, "[p]atients experience their catatonia as a terrible form of "continuous present', a term used by Gertrude Stein to describe her processing of experience through words [...]" (2012: para. 4). Additionally, Umbrella flickers between competing consciousnesses (male/female, alert/catatonic) without warning as a way of forcing us to experience both (1) Death's mechanical, dehumanized existence: "Thought is a melody, Audrey thinks, while the body is an inert mechanism of cogs, springs, chains and ratchets [...]" (Self, 2012: 75); and (2) Busner's impotency in the face of both mental disorder and cataclysmic cultural change: "I wonder, Zack - really, I wonder when it'll occur to you", Miriam, a hospital co-worker, berates Busner "that simply wishing madness away won't 
make anyone regain their sanity—nobody at all" (Self, 2012: 86). The good doctor seems implicated in Miriam's elaboration, "nobody at all". Umbrella works to bridge this gap between the promise of scientific progress and the reality of mental illness in much the same way as its antecedents, such as Thomas Mann's The magic mountain (1924) or Virginia Woolf's Mrs. Dalloway (1925). Each text presents characters who hold out hope for the possibility that a deeper understanding of the human condition will help engender a more equitable society even if such a promised land remains far off in the distance.

Even though we remain in a continuous narrative time and a single narrative consciousness in A girl is a half-formed thing, McBride's novel is no less demanding, fractured, or modern than Self's Umbrella. In a typically fractured description of the narrator's move from Western Ireland to the ambiguous "City", McBride calls to mind Georg Simmel's figure of the wandersmänner - the country woman from a foreign land who becomes part of the urban crowd, yet even after relocating herself she remains an outsider:

City all that black in my lungs. In my nose. Like I am smoking am not but still [...]. Homesick. I am. Oh God [...]. Strangers coming going here. I see in this room rolling blackboards is a new thing. But grills on windows is a what does that mean? I don't. Never seen that before. Ha. A wicked city I have come to [...]. And another one comes in and another one comes in [...]. They speak out loud and I am wrong wrong wrong. (McBride, 2014: 90-91)

In addition to her nameless characters, McBride also omits temporal and topographical detail from her text. We cannot be sure to which city the narrator has relocated. Nor do we know who these strangers are, or what they say, and why the narrator is "wrong wrong wrong". The sentiment, though, seems to be that she is wrongly placed-even if by choice. She is another in a long line of Irish self-exiles like McBride and Joyce. Reading these novels through the lens of Irish Diaspora offers us a more nuanced understanding of postcolonial modernism and its continuing significance within the larger framework of a revenant literary modernism in the early twenty-first century.

It is easy, for instance, to situate $A$ girl is a half-formed thing alongside other contemporary, feminist Irish fiction such as Anna Burns's No bones (2001), Edna O'Brien's The light of evening (2006), or Marry Morrissy's The rising of Bella Casey (2013). For two recent phenomena in Irish history - the Northern Irish Peace Process and the fall of the Catholic vanguard - have afforded contemporary artists the opportunity "to think of the nation differently, to propose alternative accounts of the nation which begin not with an idealized version of how it might be, but with how it is" (Young, 2003: 63), and, perhaps more importantly, how it was. On August 31, 1994, antagonistic political parties, the British military, and the Provisional Irish Republican Army (IRA) announced a ceasefire in Northern Ireland. The ceasefire inaugurated the Peace Process, and was followed by the Good Friday 
Agreement on April 10, 1998, which established a commitment by all parties to rely exclusively on peaceful and democratic means for reconciliation. Complete IRA disarmament occurred on October 23, 2001; peace is still precarious. In the epilogue to his study of the Northern Irish Peace Process, A secret history of the IRA, Irish journalist Ed Moloney observes, "[a]fter nineteen years of difficult, secret, and often dangerous diplomacy, Northern Ireland had finally arrived at a sort of peace" (2002: 492). Except, it did not.

In the years following the Good Friday Agreement, attention turned from lingering political imperialism to overt cultural imperialism. And while Catholicism's fall from grace in Ireland began in the 1970s, it accelerated throughout the 1990s, when a number of sexual abuse cases against its clergy became highly publicized in the media. By the end of the twentieth century, Thomas Inglis could maintain, "[s]uddenly, the Church [had] lost its sacredness and [had] become another interest group in civil society which [was] open to the same inspection as any other" (1998: 217). Mary Kenny would further declare that the "veritable avalanche of clerical scandals", finally acknowledged by the Irish government, ensured that "the very concept of 'Catholic Ireland' was by the end of the century, gone" (2000: 309). With the collapse of Catholicism as Ireland's moral compass, the conservative social agenda of Irish patriarchy also began to crumble. The fall of the Catholic vanguard in Ireland at the turn of the twenty-first century ripened the cultural moment for writers like Eimear McBride to reconsider those unacceptable, often female, threads of Ireland's national narrative. In a 2014 interview, McBride tells The White Review's David Collard,

The girl is comforted by the ritual [of Catholicism] and hopeful of the magical solutions offered by religion while her personal experience [with sex] of it is mostly oppressive and destructive. And further, she often seeks comfort in it from the very aspects of herself that have become problematic because of how her religious upbringing informs her view of that self. (Something of the church persuading women to cannibalise themselves in there too). (2014: para. 36)

While I do not want to delve too deeply into authorial intent, nor, even, a reading of $A$ girl is a half-formed thing (Irish or otherwise) as I see this essay as more theoretically focused on a recurrence of literary history, it does seem useful to consider toward what end McBride is writing. Semi-autobiographical, at least, in that she is dealing with the trauma of losing her own brother to brain cancer at the age of 28 , the novel certainly does more than provide its author with a cathartic experience. A girl is a half-formed thing and Umbrella appear to aim at a Truth reminiscent of modernism's search for grand narratives. ${ }^{3}$ So why a return to these formal techniques and to a larger search for meaning at the turn of the twentyfirst-century after postmodernism had, arguably, destroyed the notion of grand narratives altogether? 


\section{BELIEF IN A KIND OF UNIVERSALIM}

One possibility is the wide range of cultural influence enjoyed by scientific discovery in the late-twentieth century. It is not insignificant that Don DeLillo's White noise (1985), considered by many the last great novel of the postmodern era, is published the year after John Schwarz and Michael Green revealed that String Theory was free of anomalies and therefore quantum mechanically viable (1984). ${ }^{4}$ While I am not suggesting causation, there might be a correlation between the introduction of String Theory at Oxford College in the fall of 1984 and the perceived end of postmodern literature.

Brian Green, who began his doctoral studies in physics at Oxford College in the fall of 1984, explains that, "[a]lthough it is still very much a work in progress, superstring theory may well be a fully unified theory of all forces and all matter, a theory that reaches Einstein's dream and beyond - a theory, I and many others believe, that is blazing the beginnings of a trail which will one day lead us to the deepest laws of the universe" (2004: 339). Here, then, is a grand narrative (or to use the scientific terminology, a grand unifying theory), that is accepted as viable in 1984 -about the time when literary production and scholarship was once again turning its attention toward individual consciousness (particularly memory); preoccupation with time and entropy; and ambiguous, fractured texts. ${ }^{5}$

While cultural history and literary gestures are important, I have sought to define modernism not simply as a set of timely generic conventions, but as the interstice between the "promises of modernity and the realities of modernization" (Flatley, 2008: 32) where the work of re-enchantment can be done. The postcolonial agenda (and subaltern studies more specifically) fills this space, and offers readers in the twenty-first century a grand theory, global in scope, for reading the previous century's cultural bricolage. This revenant modernism, postcolonial in nature, offers a more optimistic perspective and framework for bridging the tensions and assembling the fragments that postmodern thought put on display but refused to cohere.

What I am proposing, then, runs counter to Jean-François Lyotard's dismissal of modernity's grand narratives as a consequence of "little narratives" (petits récits), which he defines as stories that affirm "singularities" and "incommensurabilities" (1984: 60). In The postmodern condition, Lyotard turned to the example of scientific discovery to illustrate his notion that "little narratives" constantly undermine grand narratives by calling into question the assumptions of those previous paradigms. But we can read scientific discovery in the other direction as well - as paradigm shifting. Superstring theory, after all, is no petit récit. Rather, it is a complete reworking of the concepts of space and time on the grandest of scales, "a fully unified theory of all forces and all matter" (Green, 2004: 339). The significance of such a discovery on literary history is renewed faith (for us, contemporary readers) in the modernist belief that "an assemblage of fragments can also become a grand narrative" (Kaiwar, 2009). 
Vasant Kaiwar argues that "[p]ostcolonial theory claims for itself the same "incredulity towards metanarratives' as postmodernism, but is it so completely innocent of advancing one of its own? For, although postcolonial theory mainly addresses the former colonial world, a reading of the literature suggests that it is global in scope and ambition" (2009: para. 25). While I agree with Kaiwar's estimation of postcolonialism as an attempt to advance a grand unifying theory, I do not do so simply because it is global in scope and ambition. And while it makes sense to suggest that postcolonial theory harbors an "incredulity towards metanarratives", I do not think it is the same "incredulity towards metanarratives" as postmodernism.

By 1995, Postcolonial Studies could be described as a "catchall term"- the seed of what would "become a seminal part of academic life" and a new grand narrative for the earlytwenty-first century (O'Brien, 2008: 41). It is interesting that 1995 is the same year in which Edward Whitten introduced Superstring, or M-theory. ${ }^{6}$ Whitten combined the five different string theories (along with a previously abandoned attempt to unify General Relativity and Quantum Mechanics called 11D-Supergravity) into one theory. "But bear in mind that no one has ever seen a string and", Brian Green warns us, "it is likely that even if string theory is right, no one ever will. Strings are so small that a direct observation would be tantamount to reading the text on this page from a distance of 100 light-years: it would require resolving power nearly a billion billion times finer than our current technology allows. Some scientists argue vociferously that a theory so removed from direct empirical testing lies in the realm of philosophy [cultural theory] or theology [the sacred], but not physics" (2004: 352). And yet physicists continue this seemingly Sisyphusean work toward visual authentication. Such an endeavor calls to mind Stephen Dedalus's "A Pisgah sight of Palestine", Will Self's Umbrella, and Eimear McBride's $A$ girl is a half-formed thing as texts of a contemporarypostcolonial modernism that strives toward equality, well knowing that there is no such thing.

In the words of Edward Said, "[o]ne of the great advances in modern cultural theory is the realization, almost universally acknowledged, that cultures are hybrid and heterogeneous and, as I argued in Culture and Imperialism, that cultures and civilizations are so interrelated and interdependent as to beggar any unitary or simply delineated description of their individuality" (1979: 347). Said's work is useful here because it answers the once seemingly insoluble question of identity politics by demonstrating that all culture is constructed, varied, and fluid. More recently, Kent Still points out how Lyotard has argued that identity formation "constitut[ing] the culture of a people"" is "[n]either grand nor petit", but "normal": "for those narratives impose a set of norms by means of which identity and consensus are established, albeit without the universal pretensions of modernity" (2007: xvi). The novels I draw upon in this essay, however, work to throw the very idea of 'normalcy' into chaos. $A$ girl is a half-formed thing ends not with the redemption of our sexually deviant narrator. She does not, that is to say, bend to the norms of society, amend her ways, and become a better person. Rather, as McBride suggests, "she has, undeniably, become herself" (Collard, 2014: 
para. 29). Similarly, Umbrella's Dr. Busner reaches the end of the narrative only to face a series of shaming failures. He is haunted by the memory of his "schizophrenic brother, Henry, who committed suicide at fifty-two, after thirty years as an inmate of psychiatric hospitals", and his still-living eldest son, Mark, "who has to wait a very long time in his Stanmore bedsit for a visit from his psychiatrist father to [...] check he's taking his medication, so that Hey, Presto! no mental illness-all gone" (Self, 2012: 396; his emphasis). And finally, the ghost of Audrey Death, "[Busner's] very own [...] Sleeping Beauty [...] her neck, gripped in the kyphotic vice of her extreme old age, curves up and over into a hook, so that leveled at him is its very blunt and accusatory end" (Self, 2012: 397). In the end, to become one's self is the least 'normal', but most 'modernist' of accomplishments.

\section{CONCLUSION: MODERNITY'S PROMISE}

In a way, novels like Umbrella and $A$ girl is a half-formed thing ask us to recognize the unfinished work of modernization - particularly, the cultural aim of human equality. Both novels restore the voices of two silenced women (one by a coma, the other by trauma) to our global narrative. As our narrators struggle to understand themselves and their environments, so too do we as readers struggle with the disjointed prose that offers us only fragments of their stories. Together, we strive for an intellectually and/or emotionally meaningful experience even if we realize that any such deeper understanding of the human condition that might help engender a more equitable society remains in a distant promised land. Of course, the experience of this journey is never the same for any two individuals. Yet, because science has proven that a "single species of string can account for a great variety of particles because the string can execute a great variety of vibrational patterns" (Green, 2004: 347; his emphasis), we can hold out hope for a grand, unifying orchestral movement wherein humanity works in concert. This, after all, is the ultimate promise of modernity, and the endgame for subaltern studies.

A renewed faith in grand narratives, then, is central to understanding literary modernism as more than a moment in time or set of generic conventions. Such faith attunes us to "the ephemeral, the fugitive, the contingent, the half of art whose other half is the eternal and the immutable" (to borrow the seminal definition of modernite from Charles Baudelaire [2006: 12]). Said another way, the specter of modernism in contemporary fiction can "offer[] society legitimation through the anticipated completion of a (as yet unrealized) master idea" (Lyotard, 1984: 4). I have suggested here, through the novels Umbrella and A girl is a half-formed thing, that this yet unrealized master idea is at least equality of the sexes, and perhaps a renewed optimism in grand narratives that even in the face of catastrophic horror afford us the opportunity to remain enchanted by the promises of modernity. 


\section{NOTES}

1 We might recall Virginia Woolf's Septimus Smith (Mrs. Dalloway), Thomas Mann's Mynheer Peeperkorn (The magic mountain), William Faulkner's Benjy Compson (The sound and the fury), Marcel Proust's narrator in À la recherche du temps perdu, and Freud's Dora. Contemporary authors working in the modernist mode — such as David Mitchell, Jeet Thayil, Marlon James, W. G. Sebald, Karl Ove Knausgård, and Andrés Neuman to name only a fewsimilarly move beyond political revolution to focus on individuals suffering under cultural oppression.

2 The narrator's confusion calls to mind Sigmund Freud's concept of the Uncanny (1919). Freud argues that the uncanny evokes fear from individuals who are confronted by a repressed belief or memory. His essay contains an explication of the German words heimlich and unheimlich (known/familiar; unknown/unfamiliar). These terms enjoy a dialectic relationship to the end that Freud can suggest "the uncanny is that species of the frightening that goes back to what was once well known and had long been familiar" (1919: 124), but has become (through repression) unfamiliarly horrifying. Other scholars will certainly do the important work of viewing this novel through the lens of trauma studies, but for my purposes here, it is primarily important to note McBride's modernist tendencies with regard to both form and content.

3 McBride recalls in David Collard's interview, "[Omission] was there from the start [as] a kind of universalism — socialist rather than posh though—was certainly my aim" (2014: para. 32).

4 Bran Nicol identifies White noise as "ficto-criticism", a text far enough removed from the peak of post-modernity in the 1960s and early 1970s from, say, Joseph Heller's Catch-22 (1961) to Thomas Pynchon's Gravity's rainbow (1973), to be considered a treatise on the postmodern condition (2009: 191).

5 For instance, we should think of Margaret Atwood's sci-fi feminist classic, The handmaiden's tale (1985); Alan Moore's structurally experimental graphic novel, The watchmen (1987); Salman Rushdie's postcolonial, dream-vision narrative Satanic verses (1988); Amy Tan's formally innovative mahong-like The joy luck club (1989); and Kazuo Ishiguro's rumination on memory construction in The remains of the day (1989).

6 It is also interesting that the Modernist Studies Association was established a mere three years later in 1998.

7 For a more detailed history of M-theory, see Becker, Becker and Schwarz (2007).

\section{REFERENCES}

Baudelaire, C. (2006). The Painter of Modern Life. In J. Mayne (Ed. and Trans.), The painter of modern life and other essays (pp. 1-41). New York, NY: Phaidon Press.

Becker, K., Becker, M. \& Schwarz, J. H. (2007). String theory and M-theory: A modern introduction. Cambridge: Cambridge University Press.

Bishop, J. (2008, December 10). Modernism and Postmodernism [Audio blog post. English 45C, Fall 2008, UC Berkeley. iTunes U]. Retrieved 2 May, 2016 from https://itunes.apple.com/us/itunes$\mathrm{u} /$ english-45c-fall-2008-uc-berkeley/id354819401?mt=10.

Collard, D. (2014, May). Interview with Eimear McBride. The White Review. Retrieved 2 May, 2016 from www.thewhitereview.org/interviews/interview-with-eimear-mcbride/.

Conrad, J. (2002). The secret sharer. In C. Watts (Ed.), Typhoon and other tales (pp. 177-217). Oxford: Oxford University Press (Original work published 1910).

Daniels, L. (2012, August 15). Umbrella by Will Self: review for Man Booker shortlist 2012. The Telegraph. Retrieved 2 May, 2016 from http://www.telegraph.co.uk/culture/books/ bookreviews/9464808/Umbrella-by-Will-Self-review-for-Man-Booker-shortlist-2012.html.

Derrida, J. (2006). Specters of Marx: The state of the debt, the work of mourning, and the new international. (P. Kamuf, Trans.). New York, NY: Routledge Classics (Original work published 1993). 
Deuteronomy 34.4. (1984). The Holy Bible, New International Version. Grand Rapids: Zondervan House.

Eliot, T. S. (1975). Ulysses, order, and myth. In F. Kermode (Ed.), Selected prose of T. S. Eliot (pp. 175-178). New York, NY: Farrar, Straus and Giroux.

Flatley, J. (2008). Affective mapping: Melancholia and the politics of modernism. Cambridge, MA: Harvard University Press.

Freud, S. (1919). The uncanny. New York, NY: Penguin Classics.

Gordon, A. F. (2008). Ghostly matters: Haunting and the sociological imagination. Minneapolis, MN: University of Minnesota Press.

Green, B. (2004). The fabric of the cosmos: Space, time, and the texture of reality. New York, NY: Vintage Books.

Inglis, T. (1998). Moral monopoly: The rise and fall of the Catholic Church in modern Ireland. (2nd ed.). Dublin: University College Dublin Press.

Jameson, F. (1991). Postmodernism, or, the cultural logic of late capitalism. Durham, NC: Duke University Press.

Joyce, J. (1993). Ulysses. (H. W. Gabler, Ed.). New York, NY: Vintage Books.

Joyce, J. (2007). A portrait of the artist as a young man. (J. P. Riquelme, Ed.). New York, NY: W.W. Norton.

Joyce, J. (2012). Finnegans wake. (R. J. Henkes, E. Bindervoet \& F. Fordham, Eds.). Oxford: Oxford University Press.

Kafka, F. (1993). “The Metamorphosis”. In G. Josipovici (Ed.), Collected Stories (pp. 73-128). (T. \& E. Muir, Trans.). New York, NY: Alfred A. Knopf (Original work published 1915).

Kaiwar, V. (2009, October 20). Colonialism, difference and exoticism in the formation of a postcolonial metanarrative. Revue LISA/LISA e-journal, 5(3). Retrieved 2 May, 2016 from http://lisa.revues.org/1537.

Kenny, M. (2000). Goodbye to Catholic Ireland. (rev. ed.). Dublin: New Island Books.

Landy, J. \& Saler, M. (2009). Introduction. In J. Landy \& M. Saler (Eds.), The re-enchantment of the world: Secular magic in a rational age (pp. 1-14). Palo Alto, CA: Stanford University Press.

Lyotard, J. F. (1984). The postmodern condition: A report on knowledge. (G. Bennington \& B. Massumi, Trans.). Theory and History of Literature (Vol. 10). Minneapolis, MN: University of Minnesota Press.

McBride, E. (2014). A girl is a half-formed thing. Minneapolis, MN: Coffee House Press.

McHale, B. (1987). Postmodernist fiction. New York, NY: Routledge.

Moloney, E. (2002). A secret history of the IRA. London: W. W. Norton.

Nicol, B. (2009). The Cambridge introduction to postmodern fiction. Cambridge: Cambridge University Press.

O'Brien, E. (2008). The return and redefinition of the repressed: The construction of female identity in the writings of James Joyce. In L. Orr (Ed.), Joyce, imperialism \& postcolonialism (pp. 4157). Syracuse, NY: Syracuse University Press.

Pound, E. (1996). CXVI. In The Cantos of Ezra Pound (p. 815). New York, NY: New Directions Publishing.

Said, E. (1979). Orientalism. New York, NY: Vintage.

Self, W. (2012). Umbrella. New York, NY: Grove Press.

Sherry, V. (2015). Modernism and the reinvention of decadence. Cambridge: Cambridge University Press.

Smythe, L. (2015). Modernism post-postmodernism: Art in the era of light modernity. Modernism/modernity, 22(2), 365-379.

Spivak, G. C. (1998). Can the subaltern speak? In C. Nelson \& L. Grossberg (Eds.), Marxism and the interpretation of culture (pp. 271-313). Basingstoke: Macmillan Education.

Still, K. (2007). Introduction. In C. Nouvet, Z. Stahuljak \& K. Still (Eds.), Minima memoria: In the wake of Jean-François Lyotard (pp. xi-xxiv). Stanford, CA: Stanford University Press.

Young, R. J. C. (2003). Postcolonialism: A very short introduction. Oxford: Oxford University Press. 